\title{
Hypotonia, Mental Retardation, Obesity, and Cryptorchidism Associated with Dwarfism and Diabetes in Children
}

\author{
BERNARD M. LAURANCE \\ From the Derbyshire Children's Hospital, Derby
}

The baby who is 'floppy' at birth invariably poses a diagnostic problem, but over the past few years new descriptions of associated clinical patterns have differentiated certain groups of disorders. One such group, only recognized during the past ten years, is presented here.

In 1956 some Swiss children were described: all were floppy at birth, had a similar facial appearance and later became obese, dwarfed, and mentally retarded (Prader, Labhart, Willi, and Fanconi, 1956b). There were both boys and girls in this group, but the boys had the additional feature of poorly developed genitalia. Some of the children developed diabetes around puberty. By 1961 a total of 14 Swiss children with this combination of disorders had been reported (Prader and Willi, 1961), and at the same time 6 similarly affected children were described in England (Laurance, 1961). Other reports from various parts of the world suggest that this is probably a relatively common syndrome, which has been confirmed by several colleagues who have kindly discussed these patients with me: 4 patients from Canada (Dunn, Ford, Auersperg, and Miller, 1961; Dunn and Miller, 1963), 1 from Sweden (Forssman and Hagberg, 1964), and 8 others from England (Evans, 1964) make up the total number of patients so far reported to 36 , including those described here.

\section{Case Histories}

All 9 children were born to healthy, non-consanguineous parents whose forbears were also healthy. All sibs of the patients were normal. Table I details ages and heights of the parents when the patients were born.

Case 1 (Male). The youngest of three children, born September 1954 by a rapid but uncomplicated breech delivery; birthweight 2900 g. (6 lb. 5 oz.). His mother had had an incomplete abortion in 1949 and a left salpingo-oophorectomy in 1950. Her blood group was A rhesus positive with anti-A agglutinins. After birth he was lethargic, cried, and sucked feebly, and limb movements were slight; colour and general appearance were normal; tendon reflexes were absent; anterior fontanelle, sutures, and fundi were normal; cephalhaematoma was present. Scrotum was poorly developed; testicles were impalpable, and the penis was very small. Subdural taps were dry. After two weeks of tubefeeding, he suckled from the breast a little, but a fortnight later was readmitted because of failure to thrive, and because generalized hypotonia persisted. Cerebrospinal fluid (CSF) was normal and repeat subdural taps were dry. Werdnig Hoffman's progressive spinal muscular atrophy was considered probable. After a period of tube-feeding he went home feeding moderately from the bottle; limb reflexes were now just obtainable. Subsequent progress was slow and he remained 'floppy', though of apparently normal intelligence. At 6 months his head was only 'bobbingly erect', but thereafter milestones were reached more quickly, so that by 8 months he sat 'propped', and by a year he pulled to the standing position. Two carpal bones were present in the wrist $x$-ray film at this time. At 18 months he had a right-sided inguinal hernia which reduced spontaneously. However, at herniorrhaphy two years later testicles were not found, but an intra-abdominal approach was

TABLE I

Ages and Height of Parents at Birth of Patients

\begin{tabular}{|c|c|c|c|c|}
\hline \multirow{2}{*}{$\begin{array}{l}\text { Case } \\
\text { No. }\end{array}$} & \multicolumn{2}{|c|}{ Age (yr.) } & \multicolumn{2}{|c|}{ Height (cm.) } \\
\hline & Mother & Father & Mother & Father \\
\hline $\begin{array}{l}1 \\
2 \\
3 \\
4 \\
5 \\
6 \\
7 \\
8 \\
9\end{array}$ & $\begin{array}{l}-\overline{33} \\
26 \\
23 \\
26 \\
26 \\
19 \\
39\end{array}$ & $\begin{array}{l}- \\
37 \\
31 \\
25 \\
29 \\
29 \\
20 \\
45\end{array}$ & $\begin{array}{l}\overline{159} \\
160 \\
163 \\
163 \\
156 \\
172 \cdot 5 \\
\overline{153}\end{array}$ & $\begin{array}{l}\overline{167} \\
160 \\
182 \\
169 \\
187 \\
188 \\
\overline{165}\end{array}$ \\
\hline
\end{tabular}

$-=$ no details available. 
TABLE II

Height, Weight, Bone-age, and Intelligence Quotient

\begin{tabular}{|c|c|c|c|c|c|c|c|c|c|c|c|}
\hline \multirow{2}{*}{ Case No. } & & \multirow{2}{*}{1} & \multirow{2}{*}{2} & \multirow{2}{*}{3} & \multirow{2}{*}{4} & \multirow{2}{*}{5} & \multirow{2}{*}{6} & \multicolumn{2}{|c|}{7} & \multirow{2}{*}{8} & \multirow{2}{*}{9} \\
\hline & & & & & & & & 1 & 2 & & \\
\hline $\begin{array}{l}\text { Age (yr. mth.) } \\
\text { Height (cm.) } \ldots \\
\text { Weight (kg.) } \\
\text { Height-age }(50 \text { centile) } \\
\text { Weight-age }(50 \text { centile) }\end{array}$ & $\begin{array}{l}\cdots \\
\cdots \\
\cdots \\
\cdots\end{array}$ & $\begin{array}{l}4 \cdot 2 \\
96 \cdot 3 \\
16 \cdot 78 \\
3 \cdot 4 \\
4 \cdot 4\end{array}$ & $\begin{array}{r}5 \cdot 5 \\
99 \cdot 3 \\
21 \cdot 8 \\
3 \cdot 8 \\
6 \cdot 3\end{array}$ & $\begin{array}{r}6 \cdot 2 \\
102 \cdot 8 \\
31 \cdot 3 \\
4 \cdot 0 \\
10 \cdot 0\end{array}$ & $\begin{array}{r}6 \cdot 0 \\
111.0 \\
30 \cdot 6 \\
5.6 \\
10 \cdot 0\end{array}$ & $\begin{aligned} 4 \cdot 5 \\
110 \cdot 2 \\
18 \cdot 6 \\
4 \cdot 3 \\
8 \cdot 10\end{aligned}$ & $\begin{array}{c}8 \cdot 10 \\
145 \\
68 \cdot 0 \\
12 \cdot 6 \\
\text { Obese }\end{array}$ & $\begin{array}{c}9 \cdot 0 \\
129 \\
43 \\
8 \cdot 4 \\
13 \cdot 0\end{array}$ & $\begin{array}{l}15 \cdot 0 \\
147 \cdot 5 \\
71 \cdot 5 \\
12 \\
\text { Adult }\end{array}$ & $\begin{array}{c}4 \cdot 7 \\
105 \\
26 \\
4 \cdot 6 \\
8\end{array}$ & $\begin{array}{r}1 \cdot 6 \\
78 \\
11 \cdot 5 \\
1.6 \\
1 \cdot 6\end{array}$ \\
\hline $\begin{array}{l}\text { Bone-age (yr. mth.) } \\
\text { IQ } \quad \ldots \\
\quad .\end{array}$ & $\begin{array}{l}\cdots \\
\cdots\end{array}$ & $\begin{array}{l}2 \cdot 3 \\
60 \\
73\end{array}$ & ${ }_{55}^{2 \cdot 6}$ & $\begin{array}{l}3 \cdot 0 \\
63 \\
72\end{array}$ & $75^{6 \cdot 5}$ & $7^{4 \cdot 5}$ & 45 & $38^{9 \cdot 10}$ & $15 \cdot 0$ & $71^{3 \cdot 0}$ & $1^{1 \cdot 6}$ \\
\hline
\end{tabular}

considered unjustified. At 4 years his speech was poorly developed (audiometry demonstrated normal hearing) and he was unquestionably mentally retarded (Table II). Although outwardly friendly and well behaved, he had increasingly frequent outbursts of viciousness towards pet animals and the other children in his foster home (the parents had now separated), and therefore he was admitted to a hospital for mentally defective children. Obesity was not a feature until after the age of 4 years when it was excessive and apparently unresponsive to dietary measures. After the age of 5 years his weight continued above the plus 2 standard deviations $(+2 \mathrm{SD})$ from the normal, though height had been on the minus 1 standard deviation ( $-1 \mathrm{SD}$ ) since birth (Fig. 1).

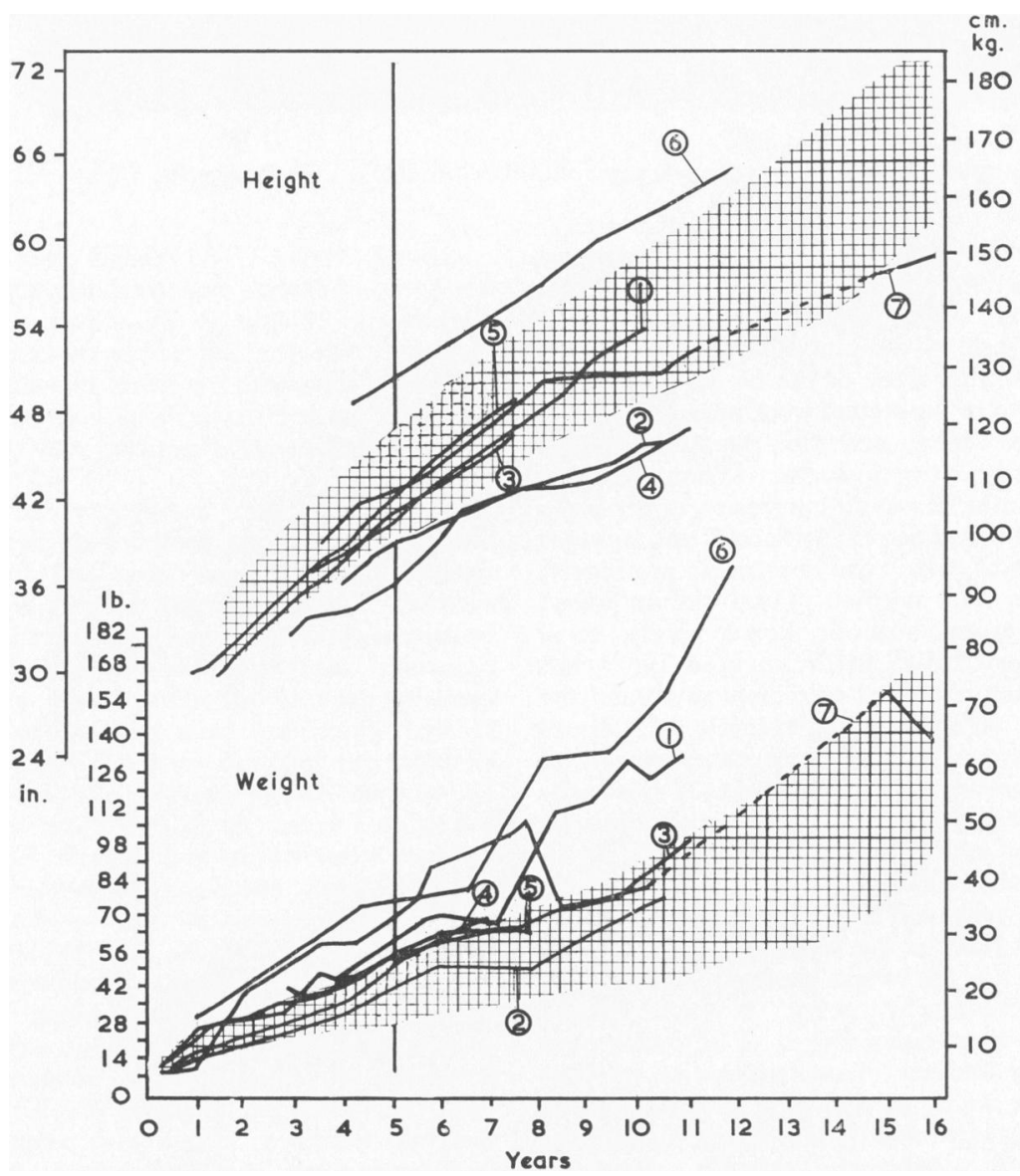

FIG. 1.-To show the height and weight increments of Cases 1-7. The shaded area covers the range 2 standard deviations above and below the mean. 


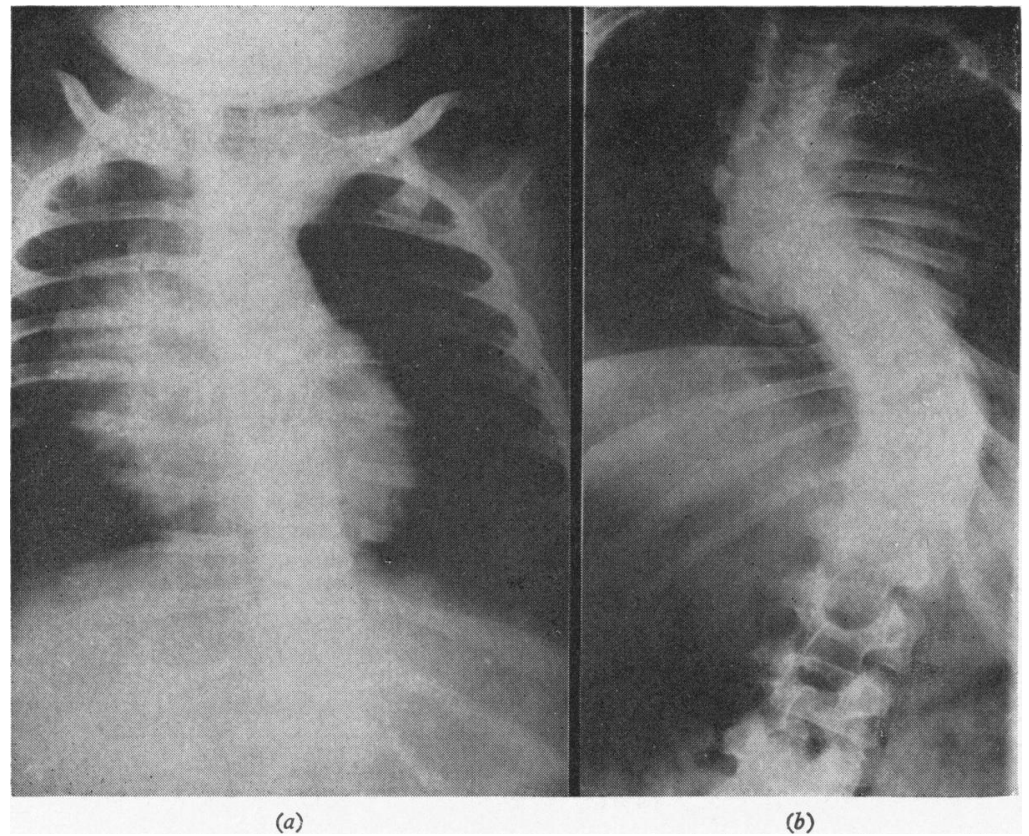

FIG. 2a and b.-To show progression of scoliosis (Case 2): (a) at 7 months; (b) at $6 \frac{1}{2}$ years.

Case 2 (Male). The youngest of four children born at full term in August 1954; placenta infarcted; birthweight $2179 \mathrm{~g}$. (4 lb. $13 \mathrm{oz}$.). The neonatal notes recorded 'the baby was asphyxiated by the umbilical cord round the neck'. During the first week of life he remained pale, rigid, and quiet, and in the second week possible athetoid movements were noted, and this 'spastic-athetoid' picture was still present at 9 weeks. When first seen personally at 6 months he was still unsteady, upper limbs and shoulder girdle were extremely flaccid, and increase in tone of lower limbs, which had been noted previously, had gone; reflexes were normal. Head circumference was $40 \mathrm{~cm}$; a spinal scoliosis noted. Very small testicles were palpated high in the inguinal canal, but even at 8 years they remained extremely small and the penis and scrotum were equally underdeveloped. By 13 months head control was almost complete, though he still could not situp but he took an interest in surroundings, played with toys, and seemed happy. Movement of all four limbs and tendon reflexes were elicited. By 19 months he could stand a little with support but could not walk alone until 3 years and 2 months; head circumference $45 \mathrm{~cm}$. At 4 years he was very fat, but after over a year on a reducing diet his weight gradually fell so that it was just below the median by 8 years. However, height, which had always been below the $-2 \mathrm{SD}$, sank even lower, presumably because of an increase in scoliosis (Fig. 2a and b) for which an operation is contemplated. Although of a strikingly friendly and happy disposition, he was educationally subnormal (Table II). Since the age of 10 years his lower legs have been thickened and extremely tender over the subcutaneous tissues.
Case 3 (Male). The second child of three children was born at full term by normal delivery in October 1953; birthweight $2971 \mathrm{~g}$. (6 lb. $9 \mathrm{oz}$.). The mother was emphatic that she felt fewer movements during this pregnancy than with her other two children. Cyanosis was sufficient at birth to require oxygen, and the cry was feeble. Because of limpness, only tube-feeding was possible.

The testicles were impalpable and the penis small. CSF contained $85 \mathrm{mg}$. protein but was normal otherwise. Haemoglobin, white cell count, and blood urea were also normal. After four weeks he took from a bottle, but, because of persistent hypotonia, a diagnosis of 'amyotonia congenita' was made. At the age of 3 years, he was again referred to hospital because of obesity (weight $21 \mathrm{~kg}$.) which had been present for a year (Fig. 3). Gonadal development was still minimal (Fig. 4). BP $110 / 70 \mathrm{~mm} . \mathrm{Hg}$; weight $4 \mathrm{~kg}$. (13 lb.) at 6 months, and $9.8 \mathrm{~kg}$. at 1 year. At 18 months he stood with support and said a few words, and he walked at 2 years. Over the years height remained below the -1 SD (Fig. 1), perhaps partly explained by dorso-lumbar scoliosis with wedged vertebrae (Fig. 5). He remained obese despite strenuous efforts at dieting. When last examined he was mentally subnormal and attending an educationally subnormal school, but was always a charming, friendly little boy - the pet of the ward. Investigations (Table II) were confirmed by Professor P. E. Polani at Guy's Hospital, London. When seen recently, it was noted that his chest was 'shield shaped' and his nipples were in the anterior axillary line (Fig. 3). There was no webbing of the neck or increase in carrying angle of the 


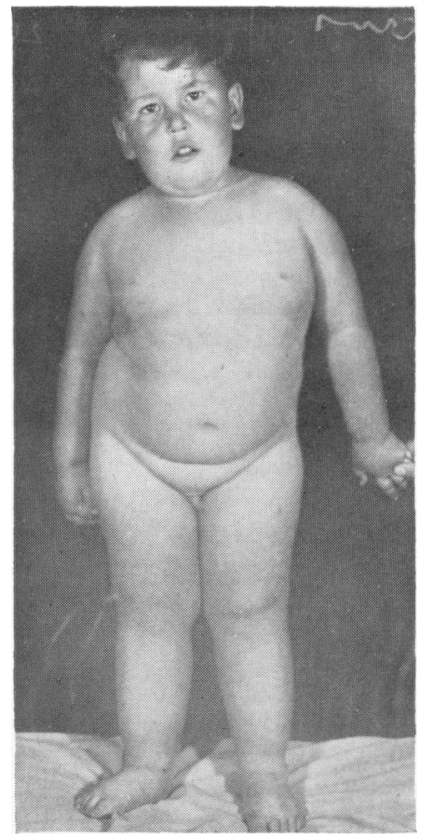

FIG. 3.-Obesity at $3 \frac{1}{2}$ years (Case 3). Note the stance due to scoliosis.

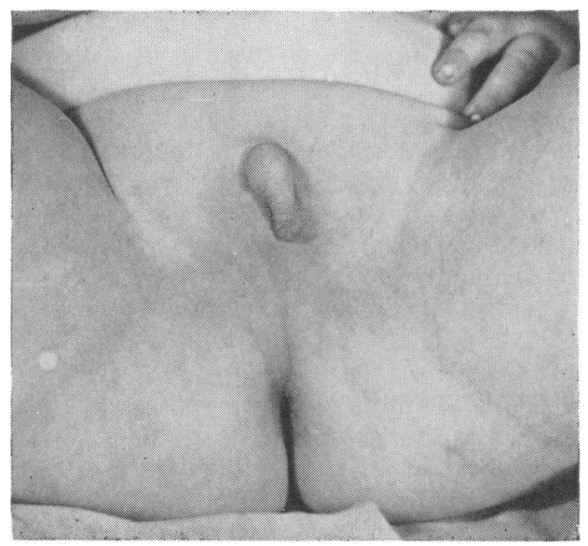

Fig. 4.-The small penis and hypoplastic scrotum at $3 \frac{1}{2}$ years (Case 3).

elbows, but his hands were narrow and fingers tapering. Thighs and lower legs were extremely 'thick', though they did not have the feeling of ordinary fat. A bilateral strabismus developed recently. Two biopsies of the thigh muscle were done at 6 and 9 years (see later).

Case 4 (Male). He was an only boy born two weeks after term by normal delivery in December 1953; birthweight 3129 g. (6 lb. 14 oz.). The neonatal notes

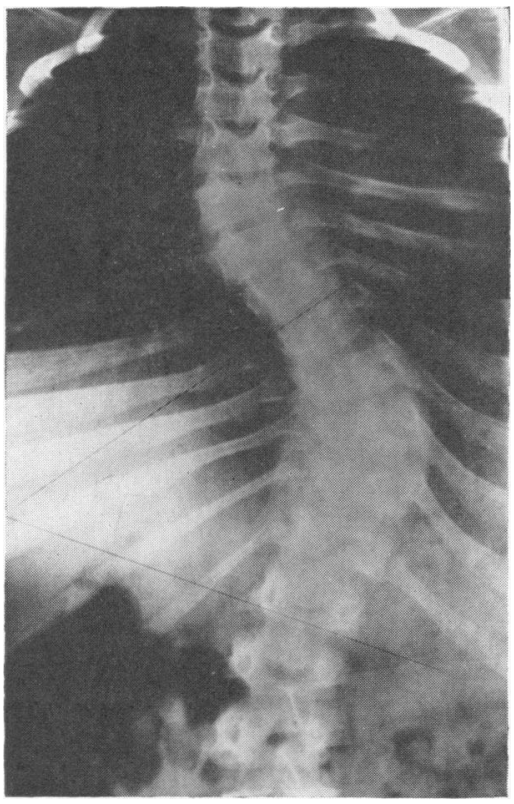

FIG. 5.-Scoliosis in Case 3.

recorded 'blue asphyxia at birth which rapidly became white asphyxia'. Because of absent limb movement and sucking he was transferred to the Derbyshire Children's Hospital on the twelfth day. Cephalhaematoma, hypotonia, and absent tendon reflexes were found. CSF was normal. By 9 weeks, he was taking feeds from the bottle, but he remained hypotonic. At the age of 4 months, he weighed $4990 \mathrm{~g}$. (11 lb.), and could spoonfeed but not suck from a bottle; he took notice, smiled, and kicked his legs, but his head was still unsteady at 6 months. By 14 months he was a plump, happy baby of $12 \mathrm{~kg}$. (27 lb.), who could not quite pull to sitting position but could stand with support. The penis and scrotum were rudimentary and no testicles were felt, though the right was thought to be present later. Strabismus was noted. By 2 years and 9 months he could run, but was gaining weight rapidly. Attempted control of obesity by diet and dextroamphetamine was ineffectual; his height remained below the $-2 \mathrm{SD}$; there was no scoliosis. At the age of 6 years it was noted that his facial appearance (Fig. 6) was similar to that of Case 3, and it is interesting that the paediatric registrar confused him with Case 1. Although outwardly friendly and happy, mental retardation was certain, and so he was admitted to a school for educationally subnormal children, and later to a training centre. In addition to investigations (see later) boneage at 9 years was approximately 10 years, i.e. normal. Testicular biopsy was done at 10 years (see later). At the age of $11 \frac{1}{2}$ years both testes were palpable but unduly small and soft.

Case 5 (Male). The second child was born by normal delivery at full-term in August 1958; birthweight $3402 \mathrm{~g}$. 


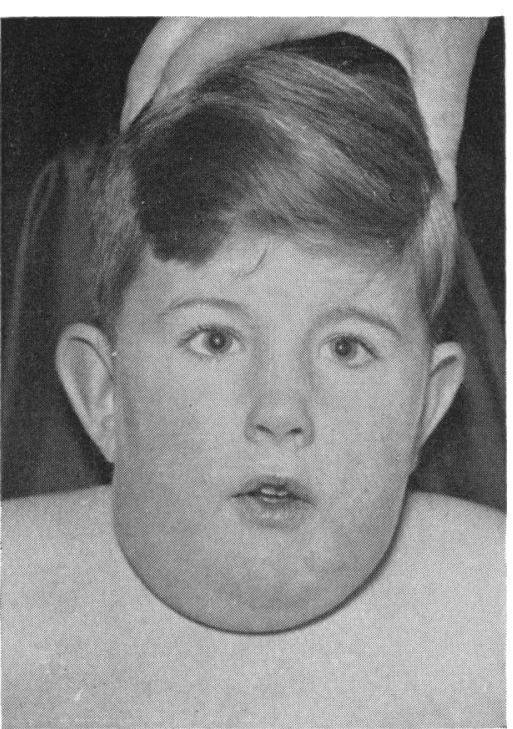

Fig. 6.-Typical facies (Case 4-aged 6 years).

$(7.5 \mathrm{lb}$.). The mother had had an ante-partum haemorrhage at 6 months. She noticed that he was more 'floppy' than her sister's children during the first year of life, but thought that this was because of his obesity. He was admitted to this hospital at the age of 11 months for repair of a right inguinal hernia. He was obese (weight $12 \mathrm{~kg}$. (27 lb. $4 \mathrm{oz}$.$) ) and had a rudimentary$ scrotum, impalpable testicles, and small penis. Head circumference was $50 \mathrm{~cm}$. Dieting was unsuccessful and his weight remained on the $+2 \mathrm{SD}$, but by 6 years it had fallen to the median (Fig. 1). At operation for strabismus at 2 years and 9 months advantage of the anaesthetic was taken to do a muscle biopsy (see 'Investigations'). At 5 years he was recommended to an educationally subnormal school as he had always been mentally slow. His manner remained friendly and happy. Genital development at 6 years was still rudimentary, though an extremely small and soft testicle was palpable on the left.

Case 6 (Male). The youngest of four children was born at full-term by normal delivery in January 1952; birthweight 3969 g. (8 lb. 12 oz.). Progress in the first six months was considered normal, though his mother described him as 'too good', because he did not cry and he kicked very little. Thereafter both weight gain and growth were very rapid, so that by the age of $10 \frac{1}{2}$ years he was above +2 SD for height and a long way above it for weight. On account of obesity and also because of not talking he was referred to this hospital at 4 years and 2 months. Milestones had been retarded; he sat at 15 months, stood at 2 years, and walked at $2 \frac{1}{2}$ years. The occasional word was said at 3 years, but speech progress was very slow. His family doctor had prescribed thyroid tablets gr. $\frac{1}{2}(30 \mathrm{mg}$.) but after two years he stopped them because they were thought to make him irritable. When last seen he was mentally retarded, obese, and tall for his age. The penis was small, but buried in suprapubic fat, and the testicles were the size of small peas. Investigations at the time showed $\mathrm{Hb} 80 \%$ (11.7 g.); cholesterol $155 \mathrm{mg} . / 100 \mathrm{ml}$. Bone-age (wrist) and skull $x$-ray films normal. These and other investigations were repeated later (see 'Investigations').

All attempts to diet him have not reduced weight. $\mathrm{He}$ attends a handicraft centre once a fortnight and is placid at home, but very nervous in hospital. At $10 \frac{1}{2}$ years the testicles were still very small; he has remained very fat.

Case 7 (Female). An only child was born by breech delivery at full term in May 1948; birthweight $2965 \mathrm{~g}$. $(6.75 \mathrm{lb}$.). Her mother had had a toxic goitre for 14 months before the birth and the paternal grandmother had also had a goitre in the past. The infant had had melaena lasting for 24 hours at the age of 5 days. Feeding was very difficult from the start, and her mother described her as a weak, inactive baby who did not cry during her first year. Bottle-feeding was impossible until the age of 1 year and 9 months, so that, not surprisingly, she only weighed $5 \cdot 25 \mathrm{~kg}$. (12 lb.) at the age of 1 year. However, presumably because of a sudden improvement in appetite at about 15 months, she weighed $19 \mathrm{~kg}$. $(40 \mathrm{lb}$.) at the age of 2 years, and could not stand. Indeed, at about this time Dr. (now Professor) D. V. Hubble, under whose care she was admitted to this hospital, wrote 'I cannot recall having seen obesity of this degree at this age'. By the age of $2 \frac{1}{2}$ years she was walking and said a few words. Despite an 800 calorie diet while in hospital she did not lose weight. At this time the skull $x$-ray film, blood cholesterol, and glucose tolerance test were reported as normal, but figures for the latter were unfortunately lost. A second attempt to diet her at the age of 8 years was more successful, for her weight fell from $48 \mathrm{~kg}$. (107 lb.) to $35 \mathrm{~kg}$. $(75 \cdot 75 \mathrm{lb}$.). When she was 10 years, she weighed $37 \frac{1}{2} \mathrm{~kg} .(82 \cdot 25 \mathrm{lb}$.) and at 11 years she weighed $43 \mathrm{~kg}$. $(93.75 \mathrm{lb}$.). Height increments lessened after the age of 8. Thereafter she was not seen by a physician until June 1963 when, at the age of 15 years, she was admitted with diabetes mellitus to the Derbyshire Royal Infirmary under the care of Dr. K. J. Gurling. Her weight was $72 \mathrm{~kg}$. and height $149 \mathrm{~cm}$. Considerable dorsal scoliosis was present. She was mentally retarded (Table II), though she could write her name. Pubic hair was present and the breasts were developed. She had one period at the age of 15, but none since. Facial appearance (Fig. 7) was strikingly similar to the previous male patients, and her long, narrow hands were also like theirs. Lower legs were indurated similar to those of Cases 2 and 3 , and the skin was almost anaesthetic to pin-prick. Diabetes failed to respond to chlorpropamide, but was eventually controlled with 40 units of insulin zinc suspension, since when she has lost weight.

Two further cases, not investigated so fully, are reported briefly. 


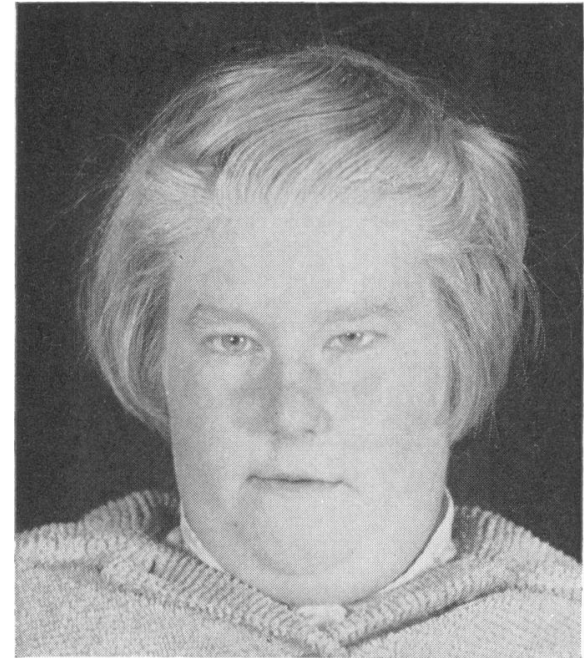

Fig. 7.-Facial appearance (Case 7).

Case 8 (Female). Born after a normal delivery at fullterm; birthweight $3.4 \mathrm{~kg}$. (7 lb.). Apgar score at 1 minute was 4 . She was pale, had a weak cry, and poor limb tone, though tendon reflexes were present. Her return home was delayed by feeble sucking from the

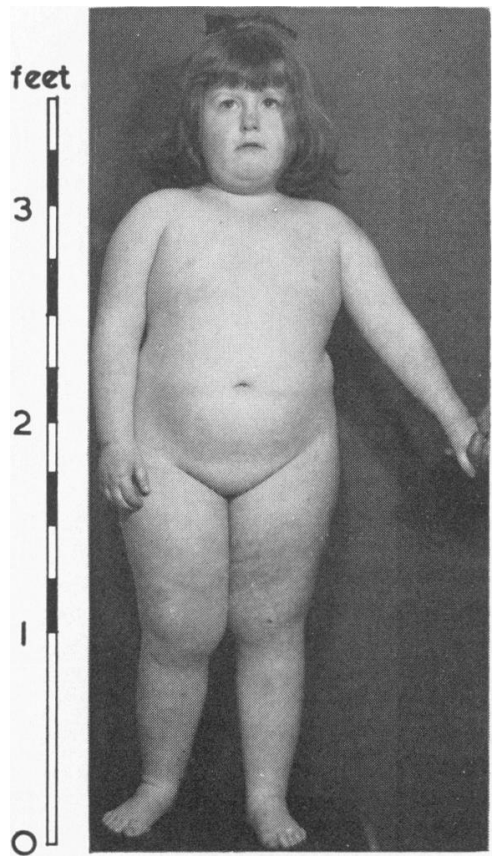

Fig. 8.-Appearance of Case 8 at 3 years of age. bottle. Limpness continued so that even at 4 months her cry was feeble and head control poor, though she now reacted to sound and smiled. Head control achieved by 9 months and she could just stand with support at 1 year, when her weight was $11 \mathrm{~kg}$. (24.25 lb.). Weight gain accelerated thereafter, i.e. $14 \mathrm{~kg}$. (32 lb.) at 18 months and $26 \mathrm{~kg}$. $(57 \mathrm{lb}$.) at 3 years and 1 month. Skull, spine, and wrist $x$-ray films were normal. Facial appearance at 18 months was suspiciously like the other children reported in this paper, and by 3 years the similarity was striking (Fig. 8). IQ low: mental age 2 years and 10 months at age of 3 years and 10 months (Merril-Palmer scale-Mr. P. R. Stevens). Speech was still indistinct at 4 years 7 months. Weight $26 \mathrm{~kg}$. $(64 \cdot 25 \mathrm{lb}$.); height $105 \mathrm{~cm}$. Chromosomes were normal. Other investigations were not done, as the child went abroad.

Case 9 (Male). Ninth child of healthy, nonconsanguineous parents whose other eight children were normal. When two months' pregnant, the mother had an undiagnosed febrile illness. The child was born two weeks after term by normal delivery; birthweight $2.9 \mathrm{~kg}$. $(5 \mathrm{lb} .12 \mathrm{oz}$.). He was extremely lethargic after birth and had to be tube-fed. All limbs were hypotonic; Moro grasp and tendon reflexes were absent. He was just as 'floppy' at 3 months, when his facial appearance resembled the other children reported in this paper. By 8 months the resemblance was striking. Testes were palpable in the inguinal canals until the age of 3 months; thereafter they were not felt and the scrotum remained rudimentary. As the hands grew, their narrow shape and puffiness of the dorsa were obvious. At 15 months he was admitted in status epilepticus for which no cause could be found, but which, on recovery, resulted in total blindness. (For investigations see later.)

\section{Investigations}

The accompanying Tables set out the results of investigations. Where applicable, the age at which they were done is indicated, but often they were spread over a number of years. They are grouped according to the body system investigated.

General. All the patients had normal haemoglobins, red and white cell counts, stool (for ova, cysts, and culture), blood urea, and serum proteins (Table III), including electrophoresis and negative Heaf or Mantoux tests. The urine was normal microscopically and there was no albuminuria, reducing substances, or aminoaciduria. The concentration and dilution test was normal where it was done (Cases 1-4 inclusive). The skull $x$-ray films were normal apart from the girl (Case 7) in whom the pituitary fossa was possibly smaller than average. Electrolytes, serum calcium, phosphorus, and alkaline phosphatase (Table III), creatine/creatinine excretion, and thyroid function (Table IV) were all normal in those cases in which these assessments were done. 
TABLE III

Biochemical Data

\begin{tabular}{|c|c|c|c|c|c|c|c|c|c|c|}
\hline $\begin{array}{l}\text { Case } \\
\text { No. }\end{array}$ & $\underset{\substack{\mathrm{Ca} \\
\mathrm{ml} .}}{\mathrm{mg} / 100}$ & $\underset{\substack{\text { ml. })}}{\mathbf{P}}$ & $\begin{array}{c}\text { Alkaline } \\
\text { Phospha- } \\
\text { tase } \\
\text { (K-A units) }\end{array}$ & $\underset{(\mathrm{mEq} / \mathrm{l} .)}{\mathrm{Na}}$ & $\underset{(\mathrm{mEq} / \mathrm{l} .)}{\mathrm{Cl}}$ & $\underset{(\mathrm{mEq} / \mathrm{l} .)}{\mathrm{K}}$ & $\underset{\underset{(\mathrm{mEq} / \mathrm{l} .) .}{\mathrm{CO}_{2}}}{\text { Powbining }}$ & $\begin{array}{c}\text { Urea } \\
\text { (mg./100 } \\
\text { ml.) }\end{array}$ & $\begin{array}{c}\text { Protein } \\
(\text { g. }, 100 \mathrm{ml} .)\end{array}$ & $\begin{array}{c}\text { Serum } \\
\text { Mg } \\
\text { (mg. } / 100 \\
\text { ml.) }\end{array}$ \\
\hline $\begin{array}{l}1 \\
2 \\
3 \\
4 \\
5 \\
6 \\
7 \\
8 \\
9\end{array}$ & $\begin{array}{c}10 \cdot 7 \\
10 \cdot 8 \\
10 \cdot 2 \\
10 \cdot 2 \\
\overline{10 \cdot 6} \\
9.3 \\
\overline{9 \cdot 4}\end{array}$ & $\begin{array}{l}3 \cdot 9 \\
5 \cdot 5 \\
4 \cdot 8 \\
3 \cdot 7 \\
-5 \cdot 1 \\
4 \cdot 2 \\
\overline{4 \cdot 2}\end{array}$ & $\begin{array}{l}25 \\
15 \cdot 6 \\
25 \\
15 \\
21 \\
25 \\
14 \cdot 6 \\
\frac{18}{18}\end{array}$ & $\begin{array}{l}134 \\
137 \\
135 \\
134 \\
138 \\
134 \\
133 \\
\frac{130}{130}\end{array}$ & $\begin{array}{r}103 \\
105 \\
105 \\
110 \\
102 \\
102 \\
93 \\
92\end{array}$ & $\begin{array}{l}3 \cdot 8 \\
5 \cdot 0 \\
5 \cdot 3 \\
3 \cdot 7 \\
4 \cdot 5 \\
4 \cdot 8 \\
3 \cdot 9 \\
5-8\end{array}$ & $\begin{array}{l}\overline{20} \\
\frac{22}{21} \\
20 \\
\overline{-} \\
26\end{array}$ & $\begin{array}{l}19 \\
31 \\
36 \\
20 \\
- \\
\frac{38}{35}\end{array}$ & $\begin{array}{l}6 \cdot 8 \\
7 \cdot 2 \\
6 \cdot 9 \\
6 \cdot 3 \\
- \\
- \\
- \\
-\end{array}$ & $\begin{array}{l}- \\
\bar{Z} \cdot 0 \\
\bar{Z} \\
- \\
-\end{array}$ \\
\hline
\end{tabular}

TABLE IV

Endocrine and Lipid Assays

\begin{tabular}{|c|c|c|c|c|c|c|c|c|c|c|c|}
\hline \multirow{2}{*}{$\begin{array}{l}\text { Case } \\
\text { No. }\end{array}$} & \multirow{2}{*}{\multicolumn{2}{|c|}{$\begin{array}{l}17 \mathrm{KS} 17 \mathrm{KGS} \\
(\mathrm{mg} \cdot / 24 \mathrm{hr} .)\end{array}$}} & \multicolumn{2}{|c|}{ Gonadotrophin } & \multirow{2}{*}{$\underset{\substack{\text { PBI } \\
\text { ml. })}}{(100}$} & \multicolumn{2}{|c|}{$\begin{array}{l}\text { Lipoproteins } \\
\text { (mg./100 ml.) }\end{array}$} & \multicolumn{4}{|c|}{ Lipid Fractions } \\
\hline & & & $\underset{20 A^{\star}}{\text { HMG }}$ & $\begin{array}{c}\text { Mouse } \\
\text { Units }\end{array}$ & & $\begin{array}{c}\text { Total } \\
\text { Cholesterol }\end{array}$ & $\begin{array}{l}\text { Total } \\
\text { Lipid }\end{array}$ & $\boldsymbol{\omega}$ & $\beta$ & $\boldsymbol{x}$ & $\beta / \alpha$ \\
\hline 1 & $\begin{array}{r}1 \\
0.6\end{array}$ & $\begin{array}{l}2 \cdot 3 \\
1 \cdot 8\end{array}$ & 0.4 & 14 & $\overline{5 \cdot 7}$ & 212 & 630 & 96 & 368 & 166 & $2 \cdot 2$ \\
\hline $\begin{array}{l}3 \\
4\end{array}$ & $\begin{array}{l}2 \cdot 3 \\
2 \cdot 1 \\
0 \cdot 8\end{array}$ & $\begin{array}{l}3 \cdot 4 \\
8 \cdot 5 \\
2 \cdot 0\end{array}$ & $\begin{array}{c}<0.4 \\
-\end{array}$ & - & $\begin{array}{l}5 \cdot 8 \\
6 \cdot 2\end{array}$ & $\begin{array}{r}203 \\
\text { (1) } 243 \\
\text { (2) } 207 \\
154\end{array}$ & $\begin{array}{l}690 \\
970 \\
600 \\
450\end{array}$ & $\begin{array}{r}118 \\
218 \\
82 \\
61\end{array}$ & $\begin{array}{l}369 \\
673 \\
366 \\
194\end{array}$ & $\begin{array}{r}203 \\
79 \\
153 \\
195\end{array}$ & $\begin{array}{l}1 \cdot 8 \\
8 \cdot 5 \\
2 \cdot 4 \\
1 \cdot 0\end{array}$ \\
\hline $\begin{array}{l}6 \\
7\end{array}$ & $\begin{array}{l}2 \cdot 6 \\
9 \cdot 1\end{array}$ & $\begin{array}{l}12 \cdot 9 \\
17-10 \cdot 2 \\
\text { OHCS }\end{array}$ & - & $\begin{array}{r}6 \\
33\end{array}$ & $6 \cdot 4$ & 153 & $\stackrel{440}{-}$ & $\frac{70}{-}$ & $\underline{254}$ & 116 & $2 \cdot 2$ \\
\hline 9 & - & - & - & 一 & 一 & 205 & - & 一 & 一 & 一 & 一 \\
\hline
\end{tabular}

$\star$ HMG 20A = Human menopausal gonadotrophin, Batch 20 A (standard used when tests were done at The Hospital for Sick Children Great Ormond Street).

Metabolic and endocrine. Growth. All the children showed a disparity between height and weight. They were excessively heavy but dwarfed (Fig. 1Cases 8 and 9 not included). Four patients (Cases 4, 6, 7 , and 8 ) have been above the +2 SD for weight (Polani, 1954) since the age of 18 months. By the age of 4 , all nine patients were at least above the median. Height, except for Case 6, was below the median in all of them, and two (Cases 2 and 3 ) had always been below the $-2 \mathrm{SD}$, while the height of Case 7 fell to below this level after the age of 15 . It was these three children who had scoliosis.

Skeletal abnormalities. Bone-age (Wilkins, 1965a) was retarded in Cases 1-3 inclusive but was within the range of normal in the rest (Table II). Scoliosis of the dorsal spine was severe in Cases 2 and 7, but only in Case 3 was it associated with wedging of the dorsal vertebrae (Fig. 5).

Adrenal and gonadotrophin functions. These were normal for age in all children in whom 17-ketogenic steroids, 17 ketosteroids, and gonadotrophin excretion were estimated (Table IV), and in whom the ACTH test (Clayton, Edwards, and Renwick, 1963) was done (Table V).
Anterior pituitary functions. The insulin sensitivity test (Daniel, 1941) and the metyrapone test (Wilkins, 1965b) were also normal whenever they were done (Tables VI and VII).

Carbohydrate metabolism. (i) Oral glucose tolerance test (Varley, 1958) (Fig. 9) was made after three days on a high carbohydrate diet; capillary blood glucose was estimated by auto-analyser. Case 2 had a curve suggestive of diabetes as the $1 \frac{1}{2}$ - and $2 \frac{1}{2}$-hour values were above $140 \mathrm{mg}$. $/ 100 \mathrm{ml}$. (Joplin, Fraser, and Keeley, 1961). Case 7 had a typical diabetic curve. All the other patients had normal curves.

(ii) Prednisone-stressed glucose tolerance test (Fig. 10) was done by the method described by Goto, Kato, Takanami, and Ohneda (1960), except that prednisone $10 \mathrm{mg}$. was given at $8 \frac{1}{2}$ hours as well as at 2 hours before the glucose tolerance test. The test was normal in Cases 1 and 3-6 inclusive and Case 9. It was not done on Cases 7 and 8 . The result in Case 2 substantiated the oral glucose curve that he was probably prediabetic; glycosuria was present at 2 and 3 hours in this patient.

(iii) Plasma insulin, Case 4 only (at age of 11 years 10 months) $30 \mu \mu / \mathrm{ml}$., i.e. normal.

Intelligence tests. The figures (Table II) refer to intelligence quotients (IQ) and more than one figure 
TABLE V

ACTH Test

\begin{tabular}{|c|c|c|c|c|c|c|c|c|c|}
\hline \multirow{3}{*}{ Day } & & \multicolumn{4}{|c|}{17 Ketosteroids (mg./24 hr.) } & \multicolumn{4}{|c|}{ Total 17-hydroxycorticoids (mg./24 hr.) } \\
\hline & & \multicolumn{4}{|c|}{ Case No. } & \multicolumn{4}{|c|}{ Case No. } \\
\hline & & 1 & 2 & 3 & 4 & 1 & 2 & 3 & 4 \\
\hline $\begin{array}{l}1 \text { (control) } \\
2 \text { ACTH .. } \\
3 \text { ACTH . } \\
4 \text { ACTH .. }\end{array}$ & $\begin{array}{l}\cdots \\
\cdots \\
\cdots \\
\cdots\end{array}$ & $\begin{array}{l}1 \cdot 4 \\
2 \cdot 9 \\
3 \cdot 1 \\
4 \cdot 3\end{array}$ & $\begin{array}{l}1 \cdot 0 \\
1 \cdot 4 \\
2 \cdot 4 \\
1 \cdot 7\end{array}$ & $\begin{array}{l}2 \cdot 1 \\
4 \cdot 8 \\
8 \cdot 7 \\
4 \cdot 2\end{array}$ & $\begin{array}{l}6 \cdot 2 \\
-\end{array}$ & $\begin{array}{r}3 \cdot 7 \\
15 \cdot 8 \\
17 \cdot 7 \\
21 \cdot 5\end{array}$ & $\begin{array}{r}3 \cdot 3 \\
6 \cdot 7 \\
15 \cdot 1 \\
11 \cdot 4\end{array}$ & $\begin{array}{r}6 \cdot 1 \\
9 \cdot 7 \\
22 \cdot 8 \\
24 \cdot 1\end{array}$ & $\begin{array}{c}13 \cdot 1 \\
25 \cdot 6 \\
56 \cdot 3 \\
\end{array}$ \\
\hline
\end{tabular}

TABLE VI

Insulin Sensitivity Test

\begin{tabular}{c|c|c|c|c|c}
\hline \multirow{2}{*}{$\begin{array}{l}\text { Case } \\
\text { No. }\end{array}$} & \multicolumn{4}{|c|}{ Blood Sugar (mg./100 ml.) } \\
\cline { 2 - 5 } & Fasting & $20 \mathrm{~min}$. & $40 \mathrm{~min}$. & $60 \mathrm{~min}$. & $120 \mathrm{~min}$. \\
\hline 2 & 68 & 76 & 56 & 34 & 40 \\
4 & 75 & 75 & 68 & 64 & 68 \\
9 & 70 & 60 & 44 & 38 & 56 \\
\hline
\end{tabular}

TABLE VII

Results of Metyrapone Test

\begin{tabular}{|c|c|c|c|c|c|c|c|c|c|c|c|c|}
\hline \multirow{3}{*}{ Day } & \multicolumn{3}{|c|}{$\underset{\text { (ml.) }}{\text { Urinary Volume }}$} & \multicolumn{3}{|c|}{$\begin{array}{l}17 \text { Ketosteroids } \\
\text { (mg./24 hr.) }\end{array}$} & \multicolumn{3}{|c|}{$\begin{array}{l}\text { 17-hydroxycorticosteroids } \\
\text { (mg./24 hr.) }\end{array}$} & \multicolumn{3}{|c|}{$\begin{array}{c}\text { Creatinine } \\
\text { (mg./24 hr.) }\end{array}$} \\
\hline & \multicolumn{3}{|c|}{ Case } & \multicolumn{3}{|c|}{ Case } & \multicolumn{3}{|c|}{ Case } & \multicolumn{3}{|c|}{ Case } \\
\hline & 2 & 3 & 4 & 2 & 3 & 4 & 2 & 3 & 4 & 2 & 3 & 4 \\
\hline $\begin{array}{l}1 \\
2 \\
3 \\
4 \\
5\end{array}$ & $\begin{array}{l}300 \\
525 \\
500 \\
775 \\
975\end{array}$ & $\begin{array}{r}260 \\
505 \\
1190 \\
330 \\
520\end{array}$ & $\begin{array}{l}\bar{Z} \\
\bar{z}\end{array}$ & $\begin{array}{l}0.54 \\
0 \cdot 81 \\
0 \cdot 6 \\
1 \cdot 3 \\
2 \cdot 4\end{array}$ & $\begin{array}{l}1 \cdot 3 \\
2 \cdot 1 \\
3 \cdot 5 \\
3 \cdot 5 \\
2 \cdot 1\end{array}$ & $\begin{array}{l}3 \cdot 8 \\
4 \cdot 4 \\
5 \cdot 8 \\
8 \cdot 6 \\
4 \cdot 6\end{array}$ & $\begin{array}{l}1 \cdot 8 \\
3 \cdot 4 \\
3 \cdot 8 \\
7 \cdot 8 \\
8 \cdot 5\end{array}$ & $\begin{array}{r}2 \cdot 1 \\
5 \cdot 6 \\
11 \cdot 2 \\
14 \cdot 6 \\
9 \cdot 0\end{array}$ & $\begin{array}{r}9 \cdot 8 \\
14 \cdot 1 \\
18 \cdot 0 \\
38 \cdot 9 \\
11 \cdot 8\end{array}$ & $\begin{array}{l}163 \\
225 \\
200 \\
265 \\
445\end{array}$ & $\begin{array}{l}\bar{Z} \\
\overline{-}\end{array}$ & $\begin{array}{l}450 \\
604 \\
515 \\
907 \\
640\end{array}$ \\
\hline
\end{tabular}

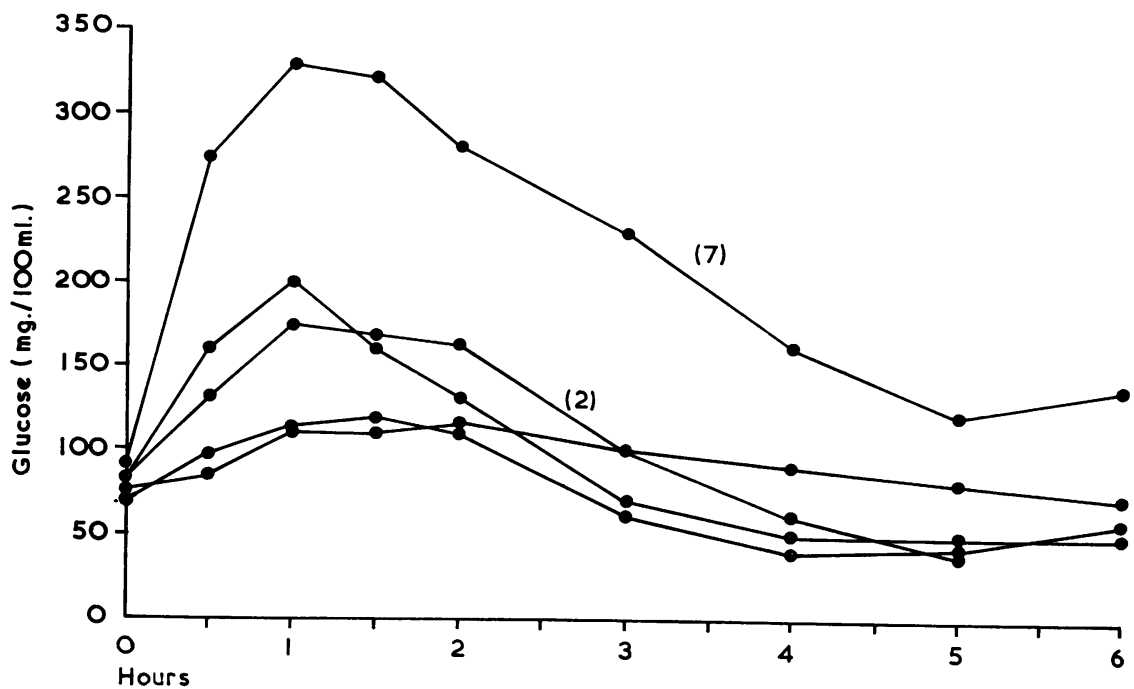

Fig. 9.-Oral glucose tolerance test (not Case 6). Figures in parentheses refer to case numbers in text. 


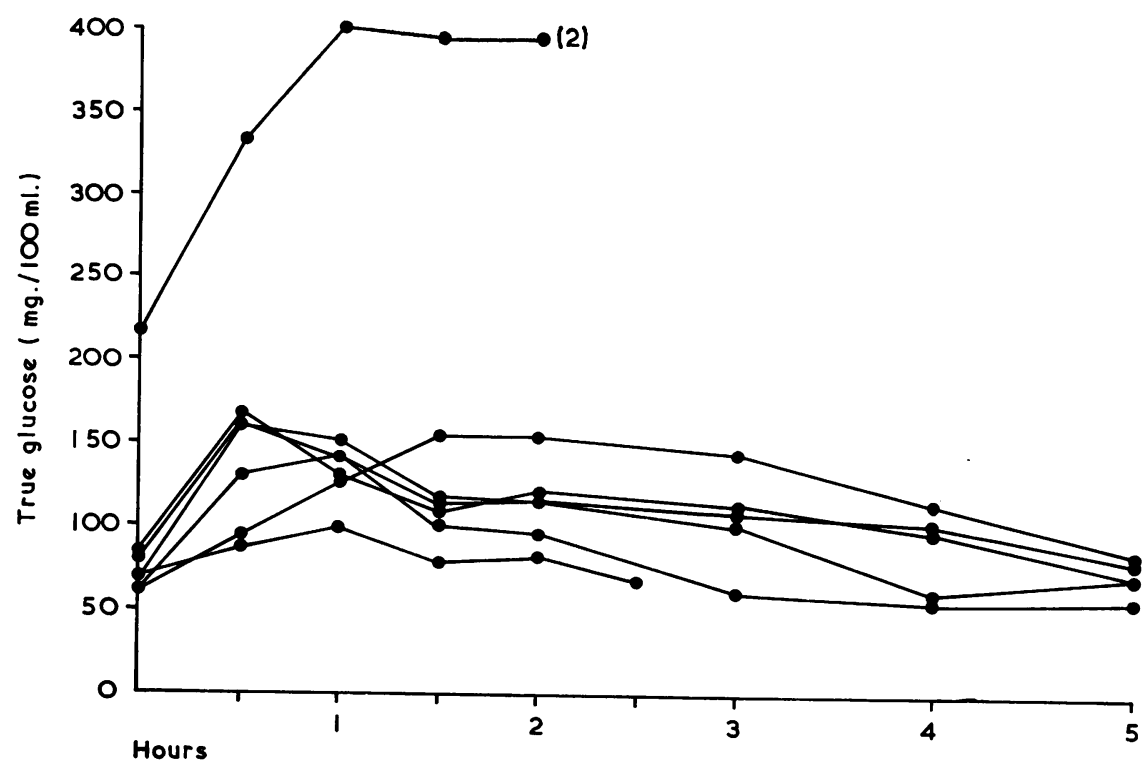

Fig. 10.-Prednisone-stressed glucose tolerance test in the boys. Figure in parentheses refers to case number in text.

indicates another test after an interval. All the children came into the educationally subnormal range, apart from two (Cases 6 and 7) who were ineducable. Case 9 was too young for testing.

Electroencephalograms. Single recordings were made on Case 1 at the age of 5 years, Cases 2 and 4 at the age of 6 years, Case 6 at 8 years, Case 7 at 15 years, and Case 9 at 15 months. In all except Cases 2 and 9 the pattern was of a posterior rhythm at 8-9 c/s, better developed in the older children, with some diffuse activity within the normal range for the age. The record of Case 2 was abnormal. The posterior rhythm was at $6 \mathrm{c} / \mathrm{s}$ with much random $4 \mathrm{c} / \mathrm{s}$ activity in frontal and central leads. A paroxysmal abnormality was also present, consisting of infrequent symmetrical runs of high voltage $4-5 \mathrm{c} / \mathrm{s}$ waves, sometimes accompanied by low voltage spikes. These paroxysms were of 1-2 seconds' duration and appeared in all leads without asymmetry. Case 9 was grossly abnormal: here the record consisted of random very high voltage $2-4 \mathrm{c} / \mathrm{s}$ waves, without asymmetry.

Muscle studies. Electromyographs. Electromyography was carried out with concentric needle electrodes on Cases $1,2,4,6$, and 7 .

The tibialis on one or other side was sampled in Cases 1, 6, and 7, the gastrocnemius in Case 4, the quadriceps in Case 2, and the extensors of the forearm in Case 7. No activity at rest was observed in any of these muscles. It was difficult to obtain co-operation for examination of the interference pattern on voluntary action, but this was certainly normal in tibialis anterior in Case 7. Nerve conduction tests were not performed.
No evidence of denervation was found. Co-operation was insufficient to exclude myopathy.

Muscle biopsies. Opportunity for doing these was taken if the child required an anaesthetic for some other reason. The biopsy from Case 2 (Dr. A. L. Woolf) was normal, but on that from Case $5 \mathrm{Dr}$. Woolf reported, 'although haematoxylin and eosin staining did not show any abnormality and cholinesterase preparations were within normal limits, vital staining with methylene blue was normal in the larger intramuscular nerve bundles, but in the smaller nerve bundles there were finely beaded fibres such as are seen in Werdnig-Hoffmann's disease although they were not present to such an extent in proportion to the number of normal looking fibres as occurs in the latter disease. I do not think that this last finding can be accepted as normal, but whether this indicates a dysplasia of the lower motor neurones or actively progressive degeneration it is impossible to decide.' A biopsy done at Guy's Hospital on Case 3 was normal and later Dr. D. V. Dubowitz found normal DPN-diaphorase, lactate dehydrogenase, phosphorylase, adenosine triphosphatase, and five nucleotidase enzyme reactions and a normal content of glycogen in this same patient.

Palm- and finger-prints (Professor Polani, Tables VIII and IX). The prints of Cases 7-9 inclusive were not examined. Two $(33 \%)$ of the six boys had an atd angle higher than $57^{\circ}$ by comparison with a maximum of $10 \%$ of the normal population and approximately $80 \%$ of mongols. Five $(83 \%)$ of the six boys had a hypothenar loop pattern, whereas a maximum of $15 \%$ of the normal population have this pattern. 
TABLE VIII

Digital Patterns in Cases 1-6

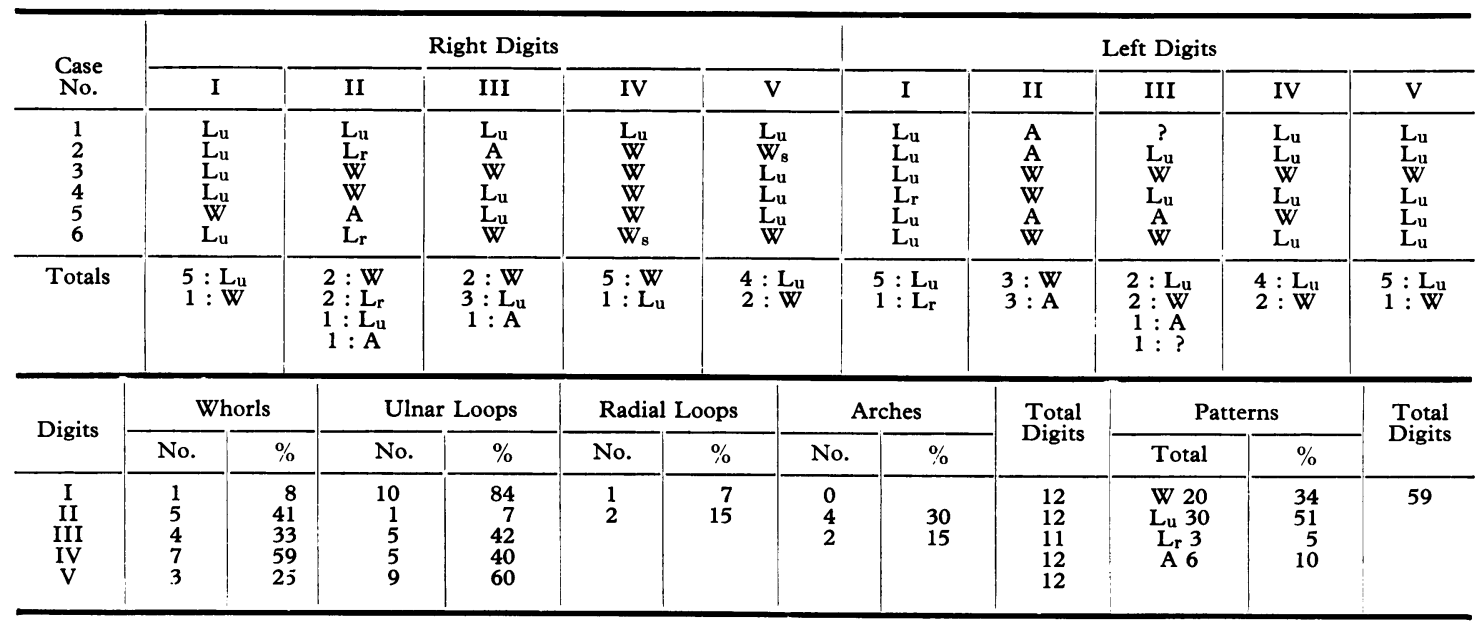

$\mathrm{L}_{\mathrm{u}}=$ Ulnar loop; $\mathrm{L}_{\mathbf{r}}=$ Radial loop; $\mathrm{W}=$ Whorl; $\mathrm{A}=$ Arch; ? $\mathrm{W}_{\mathrm{s}}=$ Whorl sign.

Blood lipoproteins (Table IV). These were normal in all the boys. (They were not done on Cases 7-9 inclusive.)

Chromatin and chromosomes (Professor Polani). All the boys (Cases 1-6 and 9) were chromatin negative and did not have any lobed polymorphs. Case 7 was chromatin positive and had lobed polymorphs.

The chromosomes were normal in five boys and in the two girls. The blood culture failed in one boy and was not done on Case 9.

Testicular biopsy. This was done on Case 4 (Fig. 11). The seminiferous tubules were normal, showing practically no mitotic activity and no production of mature spermatozoa. Interstitial cells were inconspicuous but were present in parts, and there was some interstitial oedema. There was a slight increase in Sertoli cells compared with spermatogonia. This biopsy did not differ from a group of normally descended testes in boys of the same age. There was no evidence of hypopituitary or hypothalamic abnormality as evidenced by the testes (C. L. Berry, personal communication, 1965).

\section{Discussion}

From a study of the known clinical facts about these children and of the investigations, the nature of the lesion can only be hypothetical. As Forssman and Hagberg (1964) point out, the principal features can be grouped as neuromuscular defects, mental deficiency, peculiarities in body shape, and endocrine disorders-to which I would add skeletal abnormalities. 


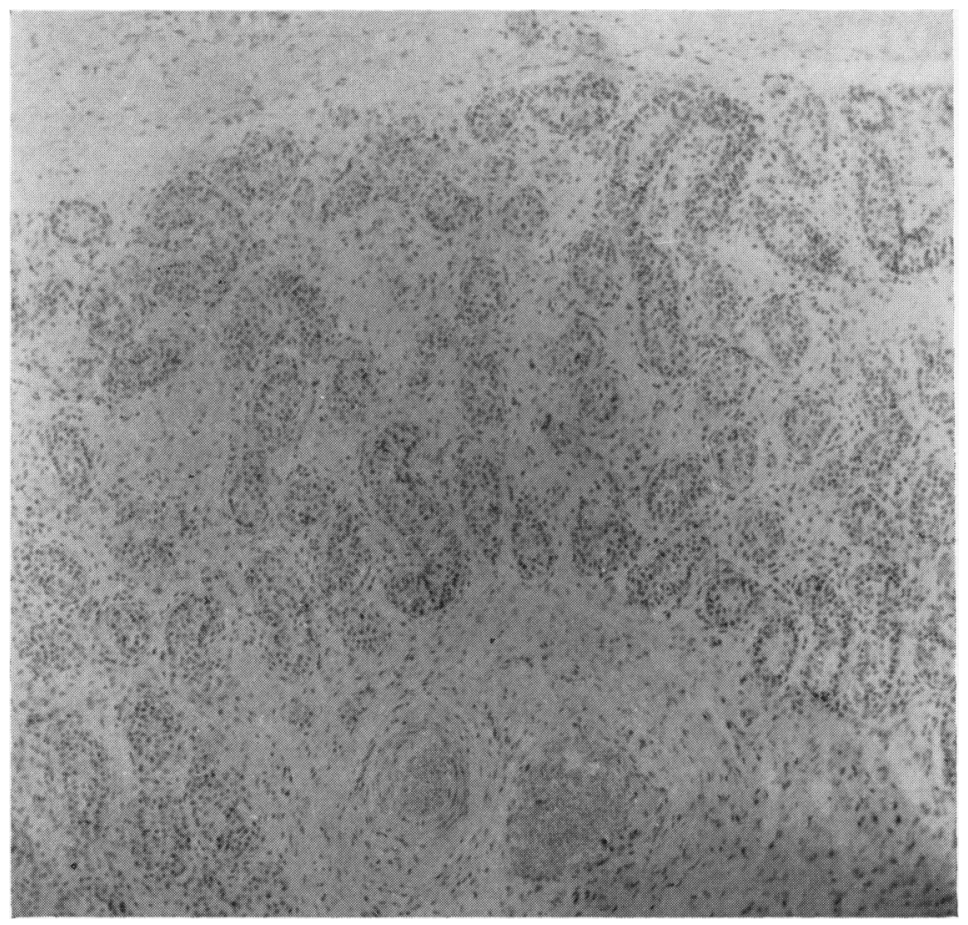

FIG. 11.-Testicular biopsy (Case 4). (× 300.)

significant of hypotonia that three of the patients reported here as well as two of Evans' eight patients had a strabismus. Dunn and Miller (1963) also reported 'abnormalities of ocular movements' in their patients. Evans (1964) reports that the patients would not, rather than could not, suck shortly after birth, and he therefore suggests that this aphagia might be the result of damage to the lateral centres in the hypothalmus. It is impossible to refute this hypothesis, but my impression is that though the babies are too weak to suck they are hungry and cry for their feeds. There is agreement that they achieve their milestones late, but that probably this is related more to their mental retardation than to their hypotonia.

Mainly because of the patients' inability to co-operate, electromyography was unhelpful. Histology of the muscles was normal in two of the three children in whom it was done. In the third it was slightly abnormal, but the significance of this is unknown. Glycogen content and enzyme reactions from a muscle biopsy of one child were normal.

Mental disorders. All the children were in the educationally subnormal range with IQs ranging from 55 to 77, apart from Cases 6 and 7 who were severely retarded (IQs 33 and 38, respectively) (Table II). As it is well known that some mentally retarded children are 'floppy' in infancy, it seems likely that the hypotonia was due to the children's poor mental state rather than to a disorder of muscle.

Their friendly co-operative natures were striking, so that they often became the pets of the ward, a feature of almost all children with this condition that I have seen in other hospitals. Nevertheless, Case 1 finally had to be admitted to a mental hospital because of his viciousness to animals and to other children. Case 6 was of much duller intellect and never seemed to have the same naïve charm of the others. Although asphyxia was mentioned in the birth notes of four babies (Cases 2, 3, 4, and 7), the degree of mental retardation did not appear to correlate with the severity of the asphyxia at birth, though the neonatal records were not always well documented on this point. The electroencephalograms did not suggest any specific pathology.

Body configuration. Although obesity was always obvious by at least the age of 4 years, in some children it was less apparent in later childhood, though even then it was excessive in relation to 
height. It was particularly marked on the lower part of the trunk and the buttocks, a feature commented upon by Evans (1964) and by Forssman and Hagberg (1964). It was not always gross, but was very striking when it was present. Moreover, in three patients (Cases 3,6, and 7) the legs were of a curiously firm consistency and seemed to have a lowered threshold to pin-prick, though the patients' dull intellect made assessment difficult. Loss of weight by dieting was extremely difficult, presumably because the poor intellect made self-denial almost impossible. However, Case 7 was conspicuously successful in this respect after the age of 15 years.

Despite this obesity, growth was retarded, i.e. below the median, and in two patients (Cases 2 and 3) was always below the -2 SD from the median, but this did not seem to be related to low birthweight. Only one patient (Case 2) was below $2250 \mathrm{~g}$. (5 lb.) at birth. Neither did the degree of dwarfing correspond to the bone-age. In four patients (Cases 1, 2, 3, and 8) the bone-age at the 50th centile was less than either the chronological or the height-age. In the other patients it was approximately the same as the chronological-age, while the height-age was below the chronologicalage except in Cases 5 and 8 where it was equal to or above (Case 6) the chronological-age.

Skeletal disorders. Scoliosis was present in three patients (Cases 2, 3, and 7) and was reflected in the falling away of height increments. The apparent fluctuation in the height of Case 3 is probably accounted for by his increasing scoliosis.
The cause of the scoliosis remains unexplained. It appears to be a common feature of this syndrome, since it is also present in a number of patients that paediatric colleagues have kindly shown me. In one (Case 3 ) there was admittedly some wedging of the dorsal vertebrae to account for this feature. Because scoliosis is not usually associated with obesity, it seemed possible that it could be accounted for by a muscle disorder but the muscle studies were disappointingly inconclusive. Two of the patients (Cases 2 and 3) have such severe scoliosis that back braces are proving ineffectual to relieve them of pain, and insertion of bone grafts is contemplated. Even allowing for the scoliosis, and it is not a universal feature, dwarfism is common in these children and retarded bone-age occurs sometimes. The relation between the dwarfism and the diabetes is discussed later. It is difficult to explain the one tall boy in this series, but it seems possible that the cause of this condition, whatever its nature, may not invariably interfere with growth.

Facies. The similarity of these children's facies was the first clinical feature that drew my attention to the condition. Indeed, when I asked Dr. Philip Evans to admit one child for chromosome studies to Guy's Hospital in 1959 he was immediately struck by the similarity between this boy and some of his own patients with the condition.

This facial similarity is obvious from a comparison of the photographs (Fig. 12) of the male patients reported here with those in the published papers (Dunn and Miller, 1963; Forssman and Hagberg, 1964; Evans, 1964). They have almond-shaped

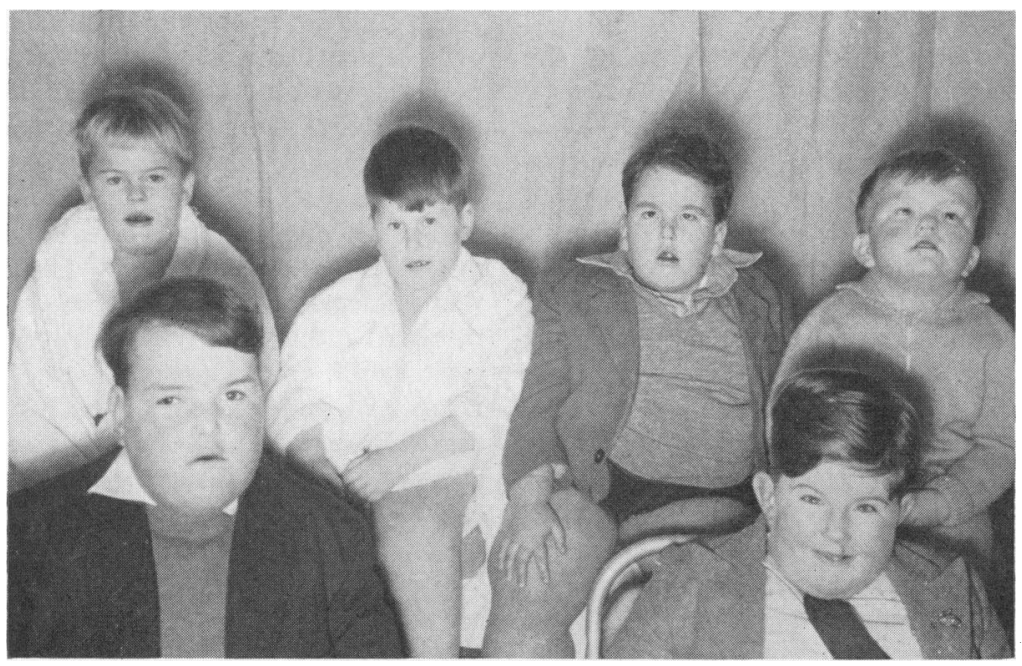

FIG. 12.-To show the similarity of the boys' facies. 
eye sockets with slightly overhanging lids, a high cranial vault above the ears when seen in profile (Fig. 13), prominent foreheads, retroussé noses, and slightly open, fish-like mouths. Their narrow hands and slim long fingers are also characteristic.

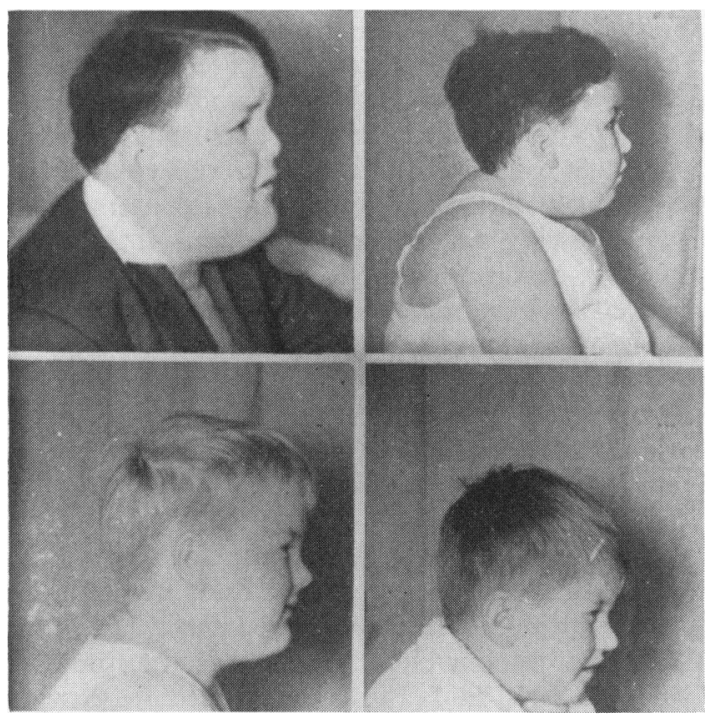

FIG. 13.-To show the similarity of the facies in profile.

Endocrine disorders. Because of the general features of these children, and particularly because diabetes had been reported in one adult of 17 (Prader et al., 1956b), endocrine studies were done. Thyroid function was normal from both the clinical and the biochemical aspects.

The serum lipoproteins were normal in all the patients on whom this test was done (Professor O. Wolff).

Adrenal function as measured by serum electrolytes, water load tests, steroid excretion, and ACTH test was normal. The metyrapone test confirmed an intact pituitary-adrenal axis in three of the patients (Cases 2, 3, and 4). The normal insulin sensitivity test in three (Cases 2,4 , and 9) confirmed normal pituitary function.

Subsequent to the report quoted above that diabetes sometimes developed in later childhood, Prader and Willi (1961) reported diabetes in patients of 12 and 17 years, respectively, while their original patient died of diabetic vascular complications at the age of 28; unfortunately permission for necropsy was refused (A. Prader, personal communication, 1965).

Of Evans's (1964) eight patients, one had frank diabetes mellitus at 15 years. The diabetic state was more of the 'adult' stable type in these three published cases. Evans's case was controlled without insulin. Of the seven reported in this paper it was only the symptoms of diabetes in Case 7 that brought the patient to hospital again. Although her diabetes was not unduly labile it proved impossible to stabilize without insulin. The boy with the pre-diabetes (Case 2) will presumably develop the full disease later, probably after puberty, judging by the other published cases.

Sex chromatin and chromosomes. Sex chromatin, as demonstrated by buccal scrapes, and lobed polymorphs were normal in the published cases on whom these investigations were done and in eight of the nine patients reported here.

Dunn and Miller (1963) reported that one of their four patients had an extra small chromosome resembling the group 21-22Y. Another boy had a long $\mathrm{Y}$. As mentioned earlier, the chromosomes were normal in seven of the patients reported here (growth failed in one) as well as in the patients reported by Forssman and Hagberg (1964).

Dunn and Miller (1963) mentioned that advanced paternal age might be related to the condition, but this was not so in the present series; neither was there consanguinity nor a familial tendency. Although a considerably larger number of males than females have so far been recognized with this syndrome, this is probably because undescended testes are a prominent feature of the syndrome.

Diabetes. Evans (1964) discusses an ingenious hypothesis to account for the diabetes. He suggests that it cannot be due to growth hormone, because these children are stunted, and that the presence of ordinary insulin antagonists is unlikely because the patients do not have ketonuria. However, he suggests that these children may have an excess of another type of insulin antagonist which is attached to plasma albumin and whose activity is dependent partly on the pituitary and partly on cortisone (Vallance-Owen and Lilley, 1961a). It interferes with glucose uptake of striated muscle (rat diaphragm) and also increases glucose uptake by fat, at least in the epididymal fat pads of the rat (Lowy, Blanshard, and Phear, 1961). Evans suggested that these children become fat and floppy because of an excess of this insulin antagonist. Furthermore, an excess of insulin antagonist can result in an increased production of insulin, which favours further production of fat (Vallance-Owen and Lilley, 1961b). Evans suggests that the children become obese because they are pre-diabetic owing to the presence of this insulin antagonist. Further studies of these 
insulin antagonists as well as of growth hormone are being investigated in these patients.

Gonadal development. The testicular biopsy on Case 4 was indistinguishable by the usual staining methods from pre-pubertal testicular biopsies in normal boys. As far as I know, spermatogenesis has not been proved in any patient so far. Menstruation occurred once only in the girl of 15 .

\section{Summary and Conclusions}

Seven boys and two girls are described whose clinical features have been sufficiently similar to constitute a syndrome that is probably commoner than the published material suggests. At birth, the patients are invariably floppy, feed poorly, and in the boys have underdeveloped scrotums and impalpable testicles. Development is slow due to mental retardation, while obesity is obvious at about the age of 3 to 4 years. The facial appearance is remarkably similar. In some of them scoliosis is a feature, and after puberty they are liable to diabetes. Their chromosomes are normal.

As the number of abnormalities constituting this syndrome is so large it seems probable that subgroups will be recognized eventually. However, at the moment this does not seem possible on either an aetiological or a pathological basis.

I should like to thank the numerous colleagues who have discussed their patients with me, in particular Drs. Barbara Clayton, P. R. Evans, and M. E. Macgregor, and Professor D. V. Hubble. Professor P. E. Polani, Mr. J. Hammerton, and many other members of the Paediatric Research Unit at Guy's Hospital, gave invaluable advice and help with the chromosomal and other investigations and Dr. A. L. Woolf (Smethwick Hospital, Birmingham) and Dr. D. V. Dubowitz (Sheffield Children's Hospital) for help with the muscle studies.

Many consultants in the Derby Group of Hospitals gave me help, especially Dr. W. B. Matthews (ECG, EEG, and electromyography), Messrs. J. Wilson and W. A. Anderson (testicular and muscle biopsies), Dr. G. R. Osborne (testicular histology), and Dr. C. W. P. Bradfield ( $x$-ray films). Mr. Wilks, Department of Medical Photography, Derbyshire Royal Infirmary, was responsible for the photographs. Dr. G. M. Komrower gave invaluable help with the draft manuscript.
REFERENCES

Clayton, B. E., Edwards, R. W. H., and Renwick, A. G. C. (1963) Adrenal function in children. Arch. Dis. Childh., 38, 49.

Conn, J. W. (1958). The prediabetic state in man; definition; interpretation and implications. Diabetes, 7, 347.

Daniel, W. A. (1941). A study of insulin tolerance and glucose tolerance tests on normal infants. $\mathcal{F}$. Pediat., 19, 789.

Dunn, H. G., Ford, D. K., Auersperg, N., and Miller, J. R. (1961). Benign congenital hypotonia with chromosomal anomaly. Pediatrics. 28, 578.

- and Miller, J. R. (1963). Benign congenital hypotonia with hypogonadism. Report of the Meeting of the American Pediatric Society, p. 57.

Evans, P. R. (1964). Hypogenital dystrophy with diabetic tendency. Guy's Hosp. Rep., 113, 207.

Forssman, H., and Hagberg, B. (1964). Prader-Willi syndrome in boy of 10 with diabetes. Acta paediat. (Uppsala), 53, 70.

Goto, Y., Kato, J., Takanami, A., and Ohneda, A. (1960). Detection of prediabetes by glucose-tolerance test sensitized by prednisolone. Lancet, 2, 461.

Joplin, G. F., Fraser, R., and Keeley, K. J. (1961). Prednisoneglycosuria test for pre-diabetes. ibid., 2, 67.

Laurance, B. M. (1961). Hypotonia, obesity, hypogonadism and mental retardation in childhood. Arch. Dis. Childh., 36, 690.

Lowy, C., Blanshard, G., and Phear, D. (1961). Antagonism of insulin by albumin. Lancet, 1,802 .

Polani, P. E. (1954). Height and Weight Charts for Boys, Medical Research Unit National Spastics Society.

Prader, A., Labhart, A., and Willi, H. (1956a). Ein Syndrom von Adipositas, Kleinwuchs, Kryptorchismus und Oligophrenie nach myatonieartigem Zustand im Neugeborenenalter. Schweiz. med. Wschr., 86, 1260.

,,-- , and Fanconi, G. (1956b). Ein Syndron von Adipositas, Kleinwuchs, Kryptorchismus und Idiotie bei Kindern und Erwachsenen, die ais Neugeborene ein MyatonieArtiges Bild geboten haben. VIII int. Congr. Paediat. Copenhagen, N.E. 10. p. 13.

- and Willi, H. (1961). Das Syndrom von Ibezillitat, Adipositas, Muskelmypotonie, Hypogenitalishus, Hypogonadismus und Diabetes Mellitus mit 'Myatonie' Anamnese. Verh. 2 Int. Kongr. Psych. Entw. Ster. Kindes-alt., Wien 1961, pt. 1, p. 353.

Vallance-Owen, J., and Lilley, M. D. (1961a). An insulin antagonist associated with plasma-albumin. Lancet, 1, 804.

- and - (1961b). Insulin antagonism in the plasma of obese diabetics in prediabetics. ibid., 1, 807.

Varley, H. (1958). Practical Clinical Biochemistry, 2nd ed., p. 420. Heinemann Medical Books, London.

Wilkins, L. (1965a). The Diagnosis and Treatment of Endocrine Disorders in Childhood and Adolescence, 3rd ed., p. 38. Thomas, Springfield, Illinois.

- $-(1965$ b). ibid., p. 359.

\section{Addendum}

Since this paper was submitted for publication, 4 more patients have been reported from France (Hooft, Deline, and Casneuf, 1966).

\section{REFERENCE}

Hooft, C.. Deline, C., and Casneuf, J. (1966). Le syndrome de Prader. Labhart-Willi-Fanconi. Acta paediat. belg., 20, 27. 